\title{
STAKEHOLDER MANAGEMENT FROM THE BUSINESS PERSPECTIVE
}

In an increasingly global and highly competitive business world of today, the business sector pays meticulous attention to stakeholders - groups or individuals, which affect or are affected by business decisions. The paper examines the methodology of identifying key stakeholders, demonstrates the process of their various mapping models, as well as the manner in which stakeholders, in cooperation with a corporation, create the opportunity to be engaged at an early stage of a project, activity or business decision, thus establishing a precedent according to which both sides benefit. By doing so, the business sector can ensure that its actions will receive "a social licence to operate", whereas various groups of stakeholders will be offered a possibility to be included in business dealings for the sake of protecting their interests. The authors of the paper have analysed a two-way process of stakeholder management in establishing corporate reputation which is reflected in business performance and results. It was concluded that stakeholder engagement should foster innovation and lead to broader social prosperity, achieving the main goal of sustainability: business excellence according to the principles of the triple final result, by realizing synergy between the social community, environment and profit.

Key words: stakeholders, engagement, reputation management, business performance

\section{Introduction}

This paper aims to confirm the necessity of analyzing the concept of a stakeholder and their engagement in various levels of the decision-making process, projects and activities, by defining the term and their respective effect in business relationships. In today's increasingly global and interconnected business world, the $21^{\text {st }}$-century company interacts with many stakeholders, meeting and managing their expectations from the perspective of "a good corporate citizen", particularly in the field of minimizing negative effects on the community and environment, advocacy and networking with civil society organizations.

In order to prove the necessity of stakeholders' analysis in reaching business decisions ${ }^{1}$, the paper will contribute by evaluating definitions of this term from

Nataša Krstić, PhD Candidate, Faculty of Finance, Economy and Administration (FEFA) Program Director “Forum Serbia Germany”, e-mail: natasa.krstic@forumsn.org

$1 \quad$ Nutt, P. C. (2002): "Why Decisions Fail: Avoiding the Blunders and Traps That Lead to Debacles”, San Francisco: Berrett- Koehler Publishers, Inc.; Freeman, E. R. (2010): "Strategic Management: A Stakeholder Approach", Cambridge University Press, pp. 363 -379. 
the point of view of business theory ${ }^{2}$ as well as provide the methodology for their mapping and engagement ${ }^{3}$, useful for management theory and business practice.

The paper aims to define managerial implications of the strategic analysis and stakeholder management, which have a positive effect on the company's profitability and market value ${ }^{4}$.

\section{Stakeholders' Review: Term, Categories, Interests}

Stakeholders are individuals, groups or organisations that affect and/or could be affected by an organisation's activities, products or services and associated performance, with regard to all the issues to be addressed by their engagement ${ }^{5}$. The term "stakeholders" is accepted globally, stemming from the word "stake", or interest, and "holder", meaning carrier, a person who officially owns something. Yet, the term is derived from the word "shareholder" or stockholder, which is comprised of the word "share", meaning portion, and "holder". The expression "stakeholders" was initially introduced by Edward R. Freeman back in 1963, defining it as "groups without whose support the organization would cease to exist". Freeman considered that the business objective should be to supplement the "general welfare" for many, individuals or groups, regardless of whether they are related or not. In Serbia, besides the term „interested parties“, which the authors believe is the most appropriate, the terms "interest groups" and the native term "stakeholders" are in use, as well.

Academic and specialized literature on this subject includes the following versions:

$2 \quad$ Clarkson, M. (1995): “A Stakeholder Framework for Analyzing and Evaluating Corporate Social Performance", Academy of Management Review. Vol. 20, No. 1/1995, pp.92-117; Eden, C., Ackermann, F. (1998): "Making Strategy: The Journey of Strategic Management", London: Sage; Murray, K.B., Vogel, C.M. (1997): “Using a Hierarchy-of Effects Approach to Gauge the Effectiveness of Corporate Social Responsibility to Generate Goodwill Toward the Firm: Financial versus Non-financial Impacts', Journal of Business Research. Vol. 38, pp. 142; Bryson, J. M. (1995): "Strategic Planning for Public and Non-profit Organizations", San Francisco. CA: Jossey- Bass

$3 \quad$ Network for Business Sustainability (2011); AccountAbility (2011)

4 Sabate, J. M., Puente, E. (2003): “Empirical analysis of the relationship between corporate reputation and financial performance: A survey of the literature", Corporate Reputation Review, Vol. 6, No. 2/2003, pp. 161-177.

5 AccountAbility (2011): „AA1000 Stakeholder Engagement Standard“, pp. 6-22

6 Freeman, E. R. (2010): “Strategic Management: A Stakeholder Approach", Cambridge University Press, pp. 363 -379. 
- Nutt and Backoff: "All parties who will be affected by, or will affect (the organization's) strategy"7 ;

- Bryson: "Any person, group or organization that can place a claim on the organization's attention, resources, or output, or is affected by that output"8;

- Murray and Vogel: "Stakeholder is every entity that influences the organization and is influenced by it. Stakeholders work: formally and informally, individually and collectively, positively and negatively"9;

- Eden and Ackermann: "People or small groups with the power to respond to, negotiate with, and change the strategic future of the organization"10;

- Johnson and Scholes: "Those individuals or groups who depend on the organization to fulfil their own goals and on whom, in turn, the organization depends" ${ }^{11}$;

- Post, Preston, Sachs: "The stakeholders in a corporation are the individuals and constituencies that contribute, either voluntarily or involuntarily, to its wealth-creating capacity by means of their activities, and that are therefore its potential beneficiaries and/or risk bearers"12;

- Jones, Felps, Bigley: "Stakeholders are those who are dependent on the firm and/or can influence the achievement of the firm's goals"13;

- Clarkson: "Stakeholders are individuals or groups that have or demand ownership rights or interest in the corporation and its activities (past, present and future). The rights or interests are the results of transactions or actions undertaken by the corporation and they can be legal or moral, individual or collective"14.

Nutt, P. C., Backoff, R. (1992): "Strategic management of Public and Third Sector Organizations: A Handbook for Leaders", San Francisco, CA: Jossey-Bass, pp. 439.

$8 \quad$ Bryson, J. M. (1995): “Strategic Planning for Public and Non-profit Organizations", San Francisco. CA: Jossey- Bass, pp. 27.

$9 \quad$ Murray, K.B., Vogel, C.M. (1997): “Using a Hierarchy-of Effects Approach to Gauge the Effectiveness of Corporate Social Responsibility to Generate Goodwill Toward the Firm: Financial versus Non-financial Impacts'. Journal of Business Research, Vol. 38, pp. 142.

10 Eden, C., Ackermann, F. (1998): “Making Strategy: The Journey of Strategic Management”, London: Sage, pp. 117.

11 Johnson, G., Scholes, K. (2002): "Exploring Corporate Strategy", 6th edition, Harlow, England: Pearson Education, pp. 206.

12 Post, J.E., Preston, L.E., Sachs, S. (2002): "Redefining the Corporation: Stakeholder Management an Organisational Wealth", Stanford University Press, pp. 229.

13 Jones, T., Felps, W., Bigley, G. (2007, Jan-Feb): "Ethical Theory and Stakeholder-Related Decisions: The Role of Stakeholder Culture", The Academy Management Review, pp. 137.

14 Clarkson, M. (1995): "A Stakeholder Framework for Analyzing and Evaluating Corporate Social Performance”, Academy of Management Review, Vol. 20, No. 1/1995, pp. 92.

Vol. 11, No 2, 2014: 165-182 
According to Freeman), stakeholder management has been recognised today as a pillar of an organisation's effectiveness, as stakeholders play important roles as advocates, sponsors, partners and agents of change ${ }^{15}$. Further, since its beginning of implementation as a principle in strategic planning, stakeholder management has developed through several dimensions and phases, as a:

- means of strategy,

- corporate communications carrier, and

- method of conceiving and implementing the strategy of corporate social responsibility and sustainability.

Bearing in mind the stakeholders' diversity and number, a company needs to decide which of them, and to what extent, should be included in its strategic issues, as all sides will not always have equal interest in certain topics or problems. Namely, a topic or problem is considered important if it probably or certainly affects decisions, shares or behaviour of one or more stakeholders, and/or the entire company. For the sake of better understanding of the influence that the business sector has on its stakeholders and vice versa, it is important to distinguish between several categories of them. According to Freeman, the main division $^{16}$ is between internal stakeholders, such as owners/shareholders, executive managers, employees, unions; and external, or partners with whom a company conducts business operations or cooperates on various levels, including competition, suppliers and other business partners, clients, media, nongovernmental organizations, state and its regulatory bodies, local and religious community, business associations, academic institutions, consumers' associations, etc.

\footnotetext{
15 Freeman, E. R. (2010): "Strategic Management: A Stakeholder Approach", Cambridge University Press, pp. 363 -379.

16 Ibid
} 
Picture 1: Division between Internal Eु External Stakeholders

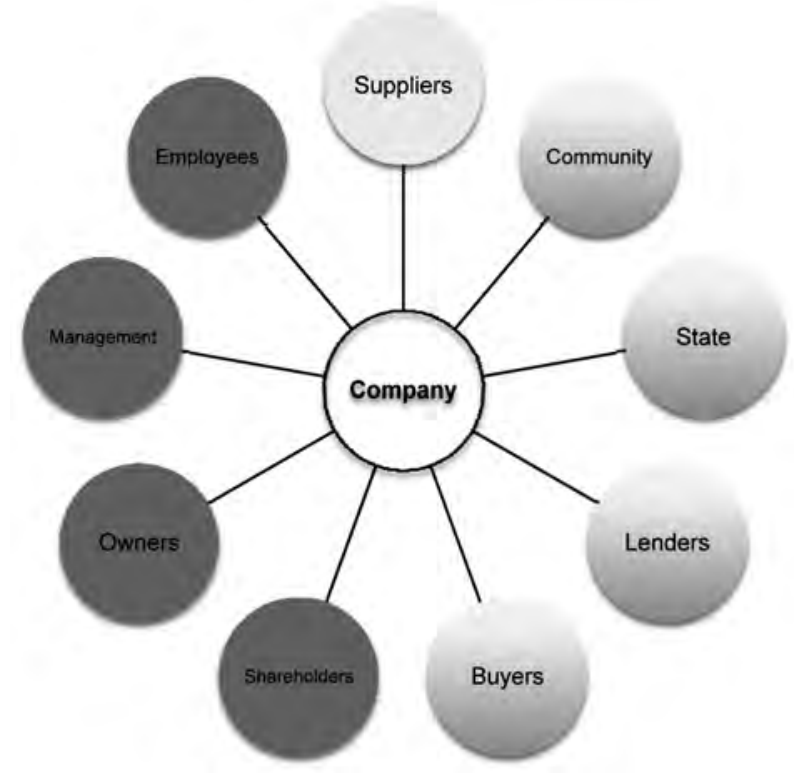

Source: Freeman, E. R. (2010): "Strategic Management: A Stakeholder Approach", Cambridge University Press

However, Mahoney proposed a distinction between active and passive stakeholders ${ }^{17}$. Active stakeholders realise direct influence on the company, e.g. in the form of voting rights which the board of directors enjoys, or are paid for their services. A growing group of passive stakeholders is beyond the direct interconnection with the company, including the local community, media, business associations and associations for the protection of the environment and consumers, that, at first glance, do not have obvious influence on the company, but can significantly contribute to the creation of its public image. We can often witness that the above mentioned groups conduct "silent" pressure on the business sector, and are capable of influencing those companies that have underestimated their influence on the local community. Furthermore, Evan and Freeman offered a division between narrow and wide stakeholders ${ }^{18}$. Narrow stakeholders are those that are mostly affected by the company's policies, and include shareholders, management, employees, suppliers, and customers (depending on the organisation's output). Wider stakeholders are less affected and may typically

\footnotetext{
17 Mahoney, J. (1994): “What makes a company ethical?", Internal Auditing, pp. 10-14.

18 Evan, W.M., Freeman, R.E. (1988): "A stakeholder theory of the modern corporation: Kantian capitalism", In T. Beauchamp \& N. Bowie. eds. "Ethical theory and business", Englewood Cliffs, Prentice Hall, pp. 75-93
} 
include the state and its agencies, less-dependent customers, the wider community (as opposed to the local community) and other peripheral groups.

Finally, stakeholders can be also divided from the perspective of the relation towards issues which are in the focus of the dialogue with the business sector into primary, secondary and key stakeholders ${ }^{19}$. Primary stakeholders are represented by individuals or groups which are under direct influence of certain projects, initiatives, institutions or organizations, regardless of them being positive or negative. In some cases, they can occur on both sides; for instance, certain regulation can be beneficial to one group, but, on contrary, can harm the other. Secondary stakeholders are individuals or groups under indirect influence of certain projects, initiatives, institutions or organizations, regardless of them being positive or negative. Finally, key stakeholders belong to one or none of the mentioned groups, realising positive or negative influence, but are of vital importance for an organization or institution that is engaged to make certain effort or conduct certain action. For example, a company General Manager can be an important stakeholder, along with some employees of lower hierarchical level directly responsible for the fulfilment of a concrete project, business goal, or assignment.

Interests that stakeholders have in contrast to the business sector can be numerous and miscellaneous. Economic interest is certainly the most prevailing. In addition, interest in social changes, labour conditions, environmental protection, physical or mental health, security and safety are frequent, too. Matching stakeholders' interests is probably one of the most critical management issues today, as it represents the mechanism by which managers monitor, provoke, and maintain the support of various groups with conflicting needs and requests. Therefore, proper balancing of stakeholder interests includes the process of assessing, weighing and addressing the opposing claims of those who have a stake in the actions of the organization ${ }^{20}$.

19 The Community Tool Box, a service of the Work Group for Community Health and Development at the University of Kansas, "Identifying and Analyzing Stakeholders and Their Interests"

20 Reynolds, S.J., Schultz, F.C., Hekman, D.R. (2006): „Stakeholder Theory and Managerial Decision-Making: Constraints and Implications of Balancing Stakeholder Interests", Journal of Business Ethics, Vol. 64, No. 3/2006, pp. 285-301. 
Table 1: Stakeholders and Interests

\begin{tabular}{|l|l|}
\hline \multicolumn{1}{|c|}{ Stakeholders } & \multicolumn{1}{c|}{ Interests } \\
\hline State & $\begin{array}{l}\text { taxes, legislation, employment, objective reporting, legal status, new } \\
\text { investments/investors }\end{array}$ \\
\hline Employees & $\begin{array}{l}\text { salaries, job security, labour conditions, respect, two-way and honest } \\
\text { communication }\end{array}$ \\
\hline Buyers, Consumers & $\begin{array}{l}\text { value and quality, post-sales service and its overall level, ethical advertising, } \\
\text { complaints mechanism }\end{array}$ \\
\hline Managers & salary, remuneration packages, privileges, realization of business goals \\
\hline Suppliers & $\begin{array}{l}\text { settlement of liabilities in due time, ethical business conduct, responsible } \\
\text { procurement policy, reference }\end{array}$ \\
\hline Lenders & rating/score card, evaluation, solvency \\
\hline Local community & $\begin{array}{l}\text { new jobs creation, environmental protection, honest dialogue, community } \\
\text { development, participation in local projects }\end{array}$ \\
\hline Union & $\begin{array}{l}\text { workers' right to decent labour, prohibition of discrimination, collective } \\
\text { contract and negotiation, employee benefits }\end{array}$ \\
\hline Owners & $\begin{array}{l}\text { profitability, prudent corporate governance, market share and position, } \\
\text { capital increase, growth, business expansion }\end{array}$ \\
\hline Investors & ROI, ROE, Principles of responsible investments, income \\
\hline
\end{tabular}

Source: The Community Tool Box

\section{Stakeholders' Analysis \& Mapping}

In today's interlinked business world, without real borders induced by globalization, stakeholder analysis becomes more important than ever before. If this topic would be elaborated from the perspective of costs in relation to users (in terms of the time invested and the needed means), it can be concluded that it is quite easy to conduct a stakeholder analysis opposite to the costs of potential failure, which might damage operations, profit, reputation, existence and relationships of an organisation. Paul Nutt made an analysis of 400 strategic decisions in his book "Why Decisions Fail", demonstrating that half of the business decisions 'failed' (status: not implemented, only partially implemented, or produced poor results) in large part because decision makers failed to attend to interests and information held by key stakeholders. Therefore, executives who wish to increase a company's potential and business results will take into consideration broad interests of stakeholders, which are influenced by its business operations. Freeman proposed that each company comprises some kind of "generic stakeholder map", where stakeholders would 
be analysed and strategically determined according to a level of influence" . This is accepted today as a good business practice and is implemented in CSR/ Sustainability reporting and/or when choosing a business strategy. Mapping is an important step to understanding who your key stakeholders are, where they come from, and what exactly they are looking for in relation to your business. Mapping can be based on any of the internal criteria used to characterise the stakeholders. For example, the owners of the engagement may wish to map level of influence against willingness to engage, type of stakeholder against level of influence, or capacity to engage and knowledge of issues against expectations . Various levels of stakeholders' influence in the company will depend on a degree of control that certain subjects have over some strategic business factors. For instance, in a situation when capital is important for the company's strategic position, its owner gets a dominant position. When capital becomes easily accessible, managerial capabilities can become an important factor, thus the company management takes over the dominant position. The map helps companies to take into consideration consequences for internal, external, active and passive stakeholders, during a process of making important, strategic business decisions. Bearing in mind that company operations change over time, along with their decision-making process, a stakeholder map is amenable to occasional revision, as current and updated stakeholder database can be a useful apparatus for executives. Ideally, it should contain details of the following:

- different stakeholder groups (their representatives, interests, problems);

- all forms and types of consultations that were held (when, on what topic, achieved results);

- all obligations taken by the company, and

- record on objections, complaints and suggestions, along with their status.

After the execution of the mapping process, a stakeholder analysis shall be conducted in order to recognize and accept their needs, problems, aspirations, authorities, general relations, mutual interaction and conduct harmonisation of such information into the stakeholder matrix. Stakeholder analysis represents a manner for the determination of positive and negative influences on certain action, a concrete project, as well as how to cooperate with stakeholders on various levels of their interest and influence. Consequently, four major attributes have been identified as important for stakeholder analysis :

- the stakeholders' position on an approach to a problem,

- the level of influence (power) they hold,

- the level of interest they have towards the specific problem,

- and the group/coalition to which they belong or can be associated with.

These attributes can be identified through various data collection methods whose use varies from available resources and influence of a certain stakeholder 
group, including polling, interviews or focus groups with experts knowledgeable about stakeholders, or with the actual stakeholders directly. The most frequent method of stakeholder analysis in business practice is the division into four groups, as presented in the chart:

\section{Picture 2: Stakeholder Mapping}

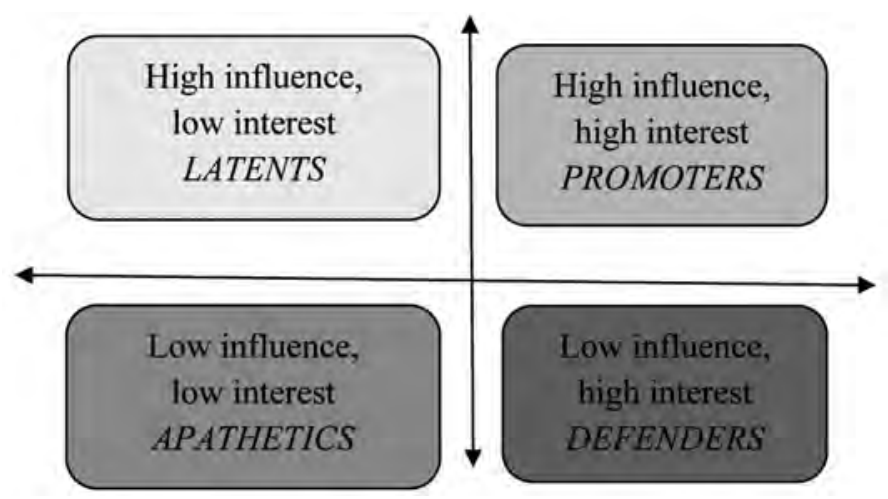

Source: The Community Tool Box

The chart shows that influence and interest can be positive or negative, depending on a stakeholder subject to mapping and analysis. Accordingly, individuals or groups that we call "key stakeholders" will be in the upper right corner of the chart, and those less important will be in the lower left, together with the following remarks:

- Promoters simultaneously have major influence in effort and power to make a certain initiative, project or organization successful, or to foil it.

- Defenders have interest and they can express their support, but have little real power to influence an initiative, project or organization in any manner.

- Latents do not have special interest or need to engage in an initiative, project or organization, but have the power to influence it significantly, should they become interested.

- Apathetics show little interest and influence and they are often unaware of an initiative, project or organization.

\section{Stakeholder Engagement}

The stakeholder engagement does not represent a novelty in business practice, but it has progressed today as a crucial factor to an organisation's sustainability and success on the market. Still, it has been difficult to fully understand 
what good or poor quality engagement represents. When a company primarily carries out its activities in the form of pre-set rules and requirements, relations with stakeholders are realized through public meetings, conferences or forums, mostly on the topics related to environmental protection and the processes taking place in the local community. This kind of "one-way consultations" is rarely effectively expanded beyond project planning stages, it is not integrated into core business activities, nor measured in terms of its effectiveness in developing constructive relationships. Today, the term "stakeholder engagement" is used as a tool to describe a broader, more comprehensive and continuous processes between entities and those parties which are potentially affected, including a range of activities and approaches throughout the duration of a project or an organization. Thus, engagement represents a process that a company uses in order to engage relevant stakeholders, for a clear purpose, and with the aim of reaching acceptable results.

Picture 3: Flowchart of Stakeholder engagement process

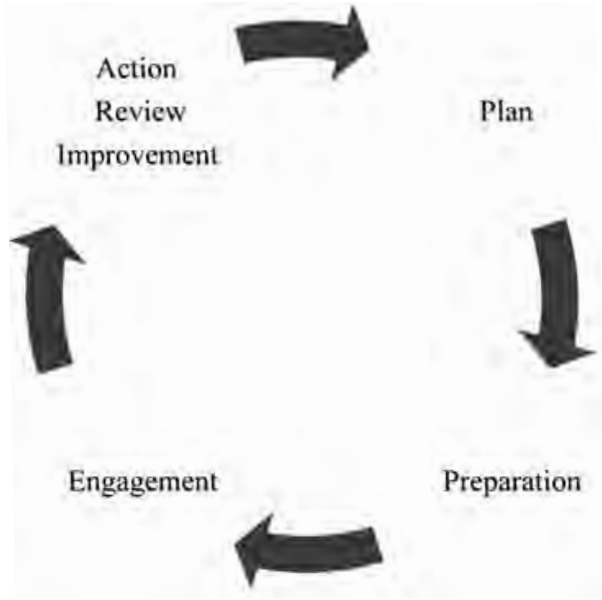

Izvor: Accountability, 2011

Stakeholder engagement is recognized today as one of the basic mechanisms of corporate social responsibility, since it obliges the business sector to engage its interested parties in the early process of identifying, understanding and addressing the issues, topics, concerns regarding sustainability, to report about and be open for explanations of the reached decisions, actions or dealing outcomes. The abovementioned reflects wider changes that have occurred in the business sector, which are quickly identifying the business, reputation-related and social risks arising from poor and one-sided relations with stakeholders, emphasizing responsibility, transparency and reporting. In this context, sound relations with stakeholders also represent the basis for prudent risk management. Namely, any stakeholder can cause or transfer business risk to different parts of a company. For example, owners can prepare a shareholder resolution that would lead to a change 
in business strategy. Customers can require changes in the policies related to environmental protection. Employees can become concerned about the management decision to shift production to a country/town with lower labour costs. NGOs can publicly criticize business practices of companies causing reputational risk in the form of negative media announcements (e.g. Shell in Nigeria, Nike in Indonesia).

Through proactive collaboration with its stakeholders, and by identifying potential problems before they become acute, a company will operate in a more stable socio-political environment. What should be noted is that building this type of relationship takes time. The basics of good relationships, such as trust, mutual respect, and understanding are intangible benefits that develop and evolve over time, based on individual/group experiences and mutual interactions. Precisely because of this, modern companies are starting to include stakeholders at a much earlier stage of a project than it used to be the case. This is particularly the case for larger, complex or more controversial projects, where companies initiate engagement at a very early stage (e.g. before drafting a feasibility study or doing research), thus signalling to the community and other stakeholders that their views on a particular subject or project have been considered as important for the purpose of achieving a common goal. In addition, early engagement of stakeholders provides a valuable opportunity to influence public opinion in the initial stages, by setting a positive tone of communication. Engagement can be a huge source of information and new productive partnerships. Leading global companies have discovered that many innovations come not only from inside, but also from outside the organizations. They understand that a stakeholder is a valuable resource, not just "a factor" to be managed. If the aforementioned becomes part of the business strategy, an opportunity is created to build relationships of trust, which can serve as a pledge in challenging times.

Picture 4: Levels of stakeholder engagement

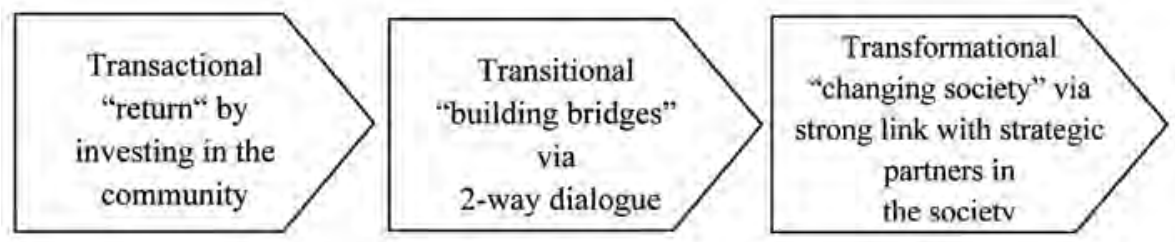

Source: Network for Business Sustainability, 2011

Picture no. 4 shows progression of three types of business behaviour during stakeholder engagement ${ }^{21}$. The transactional approach, today the most common both in literature and business practice, is based on the "giving back" mentality in the form of community investment (e.g. Alcan's Community Investment Program, AstraZeneca Global Community Support Policy). The engagement level is based

$21 \quad$ Research Network for Business Sustainability (2008, September): "Engaging the Community: A Systematic Review”, Knowledge project series, Vol. 1, Issue 1, pp. 14-15.

Vol. 11, No 2, 2014: 165-182 
on occasional interactions with a large number of partners, whereby the organisation maintains and keeps the overall control over the engagement process. Benefits of the engagement can be accumulated for both organisation and communities, but they are separately treated. If consultation and collaboration in the form of two-way communication come into the picture, we are talking about transactional stakeholders' engagement process. This approach moved beyond the one-way communication level, but still has not reached the shared sense of making common and planned decisions and problem framing of the transformational level. In the process itself, there is openness to include learning from the community, but the overall control of the entire process and its resources remains under the auspices of the organisation, rather than being fully shared. The most advanced level of stakeholder engagement today would be the transformational way, with which organisations are able to achieve outcomes which were unreachable without the engagement of the community, which takes the leadership role in framing the problem and managing the solutions. Thus, control over the engagement process is shared, allowing both sides to learn and benefit from it (e.g. Shell Living Earth program).

Table 2: Levels 83 Methods of stakeholder engagement

\begin{tabular}{|c|c|}
\hline Engagement Level & Engagement Methods \\
\hline $\begin{array}{l}\text { Consultations - limited, company asks questions, } \\
\text { stakeholders answer them }\end{array}$ & $\begin{array}{l}\text { - polls } \\
\text { - focus groups } \\
\text { - meetings with a certain stakeholder } \\
\text { - public meetings - workshops } \\
\text { - mechanism for obtaining email feedback } \\
\text { - consultative committees }\end{array}$ \\
\hline Negotiations & - collective negotiations with employees \\
\hline $\begin{array}{l}\text { Involvement - two-way or multi-engagement, } \\
\text { stakeholders and companies act independently }\end{array}$ & $\begin{array}{l}\text { - multilateral forums with stakeholders } \\
\text { - consultation panels } \\
\text { - processing based on reaching consensus } \\
\text { - participatory decision } \\
\text { - making process } \\
\text { - focus groups } \\
\text { - mechanism for obtaining email feedback }\end{array}$ \\
\hline $\begin{array}{l}\text { Collaboration - two-way or multi-engagement } \\
\text { through joint learning, decision-making and actions }\end{array}$ & $\begin{array}{l}\text { - joint projects } \\
\text { - joint investments } \\
\text { - partnerships } \\
\text { - multiple initiatives with stakeholders }\end{array}$ \\
\hline $\begin{array}{l}\text { Empowerment - new forms of responsibility, } \\
\text { decision-making is delegated to stakeholders who } \\
\text { have a certain role in decision-making }\end{array}$ & $\begin{array}{l}\text { - integration of stakeholders in the management } \\
\text { process, strategy and company management }\end{array}$ \\
\hline
\end{tabular}

Source: Accountability, 2011 
Consequently, it can be concluded that stakeholder engagement is made of high quality and strategically set, if it is based on $^{22}$ :

- $\quad$ reporting, preferably based on international standard(s), e.g. AA1000 or GRI,

- clearly defined scope,

- decision-making process that was agreed on in advance,

- topics that are material, substantial for a company and/or its stakeholders,

- creating multi-dialogue opportunities,

- corporate management, as its integral part,

- transparency,

- process appropriate for engaged stakeholders,

- accuracy, and

- flexibility.

\section{Stakeholder Management}

After deciding on the level of stakeholder engagement, a company should manage it, thus contributing to supporting its strategic long-term plans, their understanding, creating positive relationships through dealing with expectations and goals mutually agreed on. We can say that stakeholder management will sustain an organization's strategic objectives by understanding and influencing both the external and internal environments and by creating positive relationships with stakeholders through controlling their prospects and agreed objectives. Thus, stakeholder management is a process that should be carefully planned and guided by pre-defined principles. Looking into the business practice, some of the most frequent failures include ${ }^{23}$ :

- Late engagement with stakeholders, so their views cannot be considered without significant revision or delay of the project, plan or dealings;

- Too early engagement of stakeholders can cause a robust or complex decision-making process and related delays;

- Incorrect stakeholders mapping reduces the value of its contribution;

- Inconsequential treatment of stakeholders results in poor engagement at the core implementation stage.

An integral part of the management process is also a dialogue with stakeholders, which should determine the way in which information is mutually

22 Account Ability (2011): "AA1000 Stakeholder Engagement Standard", pp. 27

23 Krstić Nataša (2014): "Development of Corporate Social Responsibility as part of Serbian Companies' Management Strategy", Doctoral thesis, University Singidunum, Faculty of Finance, Economy and Administration, p. 123. 
transmitted, based on the principle of "who, when and to what extent". The dialogue with stakeholders is an important source of information that improves dealings and results, as well as the relationship with the local community, and helps a company recognize and control business risks. In addition, management capabilities are also improved and so is the volume of activities carried out by a company, as this creates legitimacy of the decisions made. For stakeholders, a dialogue with the business sector is an opportunity to raise important questions about their concerns and expectations, as well as the possibility of potential participation in decision-making. With the aim of implementing a good quality, two-way and continuous dialogue, companies often start drafting a communication plan, where the level of the dialogue, model and intensity depend on the level of influence of specific stakeholders and their organizational forms. The level of influence is based on the mix between the level of power and the level of interest, as shown in the Picture 5.

Picture 5: Stakeholders' Management according to their Importance

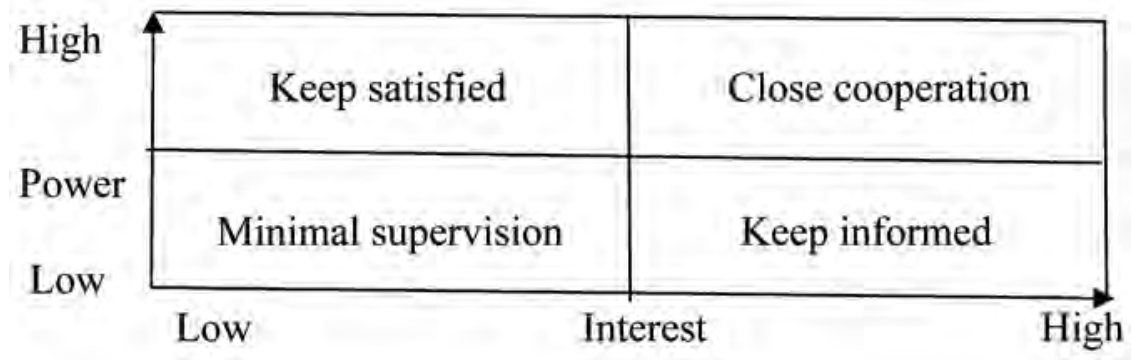

Source: Network for Business Sustainability (2011): "Stakeholder engagement"

Some of them request simple and sporadic updates, while others have the need for a regular, detailed and frequent dialogue. The means of communication can incorporate the following ${ }^{24}$ :

- official meetings with influential stakeholders;

- unofficial meetings with stakeholders;

- mailing lists for sending information about the progress in certain areas or stages of a project;

- informative, electronic or printed letters or newspapers;

- the company's internet presentation;

- individual informative meetings (briefings), presentations, podcasts ${ }^{25}$;

$24 \quad$ Krstić Nataša (2014): "Development of Corporate Social Responsibility as part of Serbian Companies' Management Strategy”, Doctoral thesis, University Singidunum, Faculty of Finance, Economy and Administration, p. 124-125

25 Podcast is a digital database that contains audio or video material distributed via Internet and is designed for watching or listening on computer, digital portable player or television. 
- $\quad$ public forums, suitable for addressing stakeholders in a local community;

- press releases, media interviews;

- advertising, advertorials;

- $\quad$ establishing specialized committees or task forces comprised of stakeholders who share a common goal or interest.

\section{Conclusion}

The $21^{\text {st }}$-century organisation interacts, directly or indirectly, with a large scale of various stakeholders, in the form of individuals or groups, with or without mutual interest, which are affected or which affect their dealings. As a result of this relationship, acceptance of a company depends on its strategies and decisions in the society and community. Modern management theories and business practice increasingly place stakeholders' engagement in their focus with the aim of lowering the possibility of making wrong decisions or leading projects and processes to a standstill, but also with the aim of achieving responsible and innovative corporate culture.

The paper indicated the fact that the business sector of today should be governed by ecological, societal and management aims so as to provide long-term sustainability on the market. A two-way communication and cooperation with stakeholders represents the business model of the future which confirms that there is no business success in underdeveloped society, and vice versa. If cooperation is well structured, it contributes to better risk and reputation management, economising with available business resources (expertise, financial means, technologies) with the aim of problem solving, achieving goals that a company cannot achieve by itself, understanding complex work environments, learning process of the business sector from stakeholders and improved products/services and processes. 


\section{Literature}

- AccountAbility (2011): "AA1000 Stakeholder Engagement Standard", pp.6-22. http://www.accountability.org/images/content/3/6/362/AA1000SES\%20 2010\%20PRINT.PDF (25.07.2014).

- Barnett L. Michael (2007): "Stakeholder influence capacity and the variability of financial returns to corporate social responsibility", Academy of Management Review, Vol. 32, No.3/2007, pp. 794-816.

- Bryson M. John (1995): "Strategic Planning for Public and Non-profit Organizations", San Francisco, CA: Jossey- Bass

- Clarkson Max (1995): "A Stakeholder Framework for Analyzing and Evaluating Corporate Social Performance", Academy of Management Review, Vol. 20, No. 1/1995, pp. 92-117

- Eden Colin, Ackermann Frank (1998): “Making Strategy: The Journey of Strategic Management”, London, Sage

- Evan M. William, Freeman R. Edward (1988): “A stakeholder theory of the modern corporation: Kantian capitalism" in: Tom Beauchamp \& Norman Bowie (eds.): "Ethical theory and business", Englewood Cliffs, Prentice Hall

- Freeman R. Edward (2010): "Strategic Management: A Stakeholder Approach”, Cambridge University Press, pp. 363-379

- Global Reporting Initiative (2013): "Implementation Manual - Version G4”, pp. 43. https://www.globalreporting.org/reporting/g4/Pages/default.aspx (1.09.2014).

- Johnson Gerry, Scholes Kevin (2002): "Exploring Corporate Strategy", Harlow, England, Pearson Education

- Jones Thomas, Phelps Will, Bigley Gregory (2007): "Ethical Theory and Stakeholder-Related Decisions: The Role of Stakeholder Culture", The Academy Management Review, No. 1-2/2007, pp. 137-155

- Krstić Nataša (2014): "Development of Corporate Social Responsibility as part of Serbian Companies' Management Strategy”, Doctoral thesis, University Singidunum, Faculty of Finance, Economy and Administration

- Krstovic Jelena, Vlastelica Bakić Tamara, Kostic Cicvaric Slavica (2012): "The Role of Business in the Society", Management, No. 62/2012, pp. 75-76

- Lankoski Leena, Smith N. Craig, Wassenhove Luk Van (2011): “Judgement of stakeholder value: Advancing stakeholder theory through prospect theory", Insead

- Mahoney John (1994): "What makes a company ethical?", Internal Auditing, pp. 10-14

- Miles Samantha (2012): "Stakeholders: essentially contested or just confused”, Journal of Business Ethics, Vol. 108, No. 3/2012, pp. 285-298 
- $\quad$ Murray B. Keith, Vogel M. Christine (1997): "Using a Hierarchy-of Effects Approach to Gauge the Effectiveness of Corporate Social Responsibility to Generate Goodwill Toward the Firm: Financial versus Non-financial Impacts", Journal of Business Research, No. 38/1997, pp. 142

- Network for Business Sustainability (2011): "Stakeholder engagement". www.nbs.net (13.09.2014).

- Paul C. Nutt (2002): "Why Decisions Fail: Avoiding the Blunders and Traps That Lead to Debacles". San Francisco, Berrett- Koehler Publishers

- Paul C. Nutt, Robert Backoff (1992): "Strategic management of Public and Third Sector Organizations: A Handbook for Leaders", San Francisco, CA: Jossey-Bass

- $\quad$ Post E. James, Preston E. Lee, Sachs Sybille (2002): "Redefining the Corporation: Stakeholder Management an Organisational Wealth", Stanford University Press, pp. 46-56, 229-254

- Puncheva-Michelloti Petya, Michelotti Marco (2010): “The role of the stakeholder perspective in measuring corporate reputation", Marketing Intelligent \& Planning, Vol. 28, No. 3/2010, pp. 249-274

- Research Network for Business Sustainability (2008): "Engaging the Community: A Systematic Review", Knowledge project series, Vol. 1, No. 1/2008, pp. 14-15

- Reynolds J. Scott, Schultz C. Frank, Hekman R. David (2006): "Stakeholder Theory and Managerial Decision-Making: Constraints and Implications of Balancing Stakeholder Interests", Journal of Business Ethics, Vol. 64, No. 3/2006, pp. 285-301

- Sabate Juan Manuel de la Fuente, Puente Esther de Quevedo (2003): "Empirical analysis of the relationship between corporate reputation and financial performance: A survey of the literature", Corporate Reputation Review, Vol. 6, No. 2/2003, pp. 161-177.

- The Community Tool Box, a service of the Work Group for Community Health and Development at the University of Kansas, "Identifying and Analyzing Stakeholders and Their Interests"

- http://ctb.ku.edu/en/table-of-contents/participation/encouraging-involvement/identify-stakeholders/main (18.09.2014)

- http://ctb.ku.edu/en/table-of-contents/participation/encouraging-involvement/identify-stakeholders/checklist (18.09.2014)

- The World Bank Group, "Stakeholder Analysis", wwwl.worldbank.org/ publicsector/anticorrupt/PoliticalEconomy/stakeholderanalysis.htm (19.09.2014) 


\title{
Mr Nataša Krstić
}

Doktorand na Fakultetu za finansije, ekonomiju i administraciju (FEFA), Programski direktor "Foruma Srbija Nemačka"

\section{UPRAVLJANJE STEJKHOLDERIMA IZ POSLOVNE PERSPEKTIVE}

\begin{abstract}
S a ž e t a k
U današnje doba globalizacije i izražene tržišne kompetitivnosti, poslovni sektor poklanja veliku pažnju stejkholderima - grupama ili pojedincima, koji utiču, ili na koje se utiče poslovnim odlukama. U radu je analizirana metodologija identifikovanja ključnih stejkholdera, objašnjen je proces različitih modela njihovog mapiranja i način kako stejkholderi ostvaruju mogućnost da u saradnji sa kompanijom budu uključeni u ranu fazu projekta, aktivnosti ili poslovne odluke, ostvarujući model po kom su obe strane na dobitku. Na taj način, poslovni sektor može da osigura da će njegove aktivnosti dobiti "društvenu licencu za poslovanje“, dok različite grupe stajkholdera imaju mogućnost da budu uključene u poslovanje radi zaštite njihovih interesa. Autori su analizirali dvosmernu ulogu procesa upravljanja odnosima sa stejkholderima u izgradnji korporativne reputacije, koja se odražava na poslovne performanse i rezultate. Zaključeno je da uključivanje stejkholdera može da unapredi kulturu inovacija i dovede do šireg društvenog blagostanja, ostvarujući primarni cilj održivosti: poslovnu izuzetnost po principima trostrukog krajnjeg rezultata, ostvarenjem sinergije izmedju društvene zajednice, životne sredine i ostvarenja dobiti.
\end{abstract}

Ključne reči: stejkholderi, uključivanje, upravljanje reputacijom, poslovne performanse 